\title{
Impact of Covid_19 on E-commerce (From a Legal Point of View)
}

\author{
Khaled Abed Alshakhanbeh ${ }^{1}$ \\ ${ }^{1}$ The World Islamic Sciences and Education University, Amman, Jordan \\ Correspondence: Khaled Abed Alshakhanbeh, Associate Professor in Commercial Law, The World Islamic \\ Sciences and Education University, Amman, Jordan. E-mail: khaled@shakhanbehlaw.com
}

Received: September 14, 2021

doi:10.5539/jpl.v15n1p1

\author{
Accepted: October 19, $2021 \quad$ Online Published: October 29, 2021 \\ URL: https://doi.org/10.5539/jpl.v15n1p1
}

\begin{abstract}
The spread of the Corona virus and the closure of borders and the ban on travel and commercial bodies in companies, which resorted to many commercial activities, relying on a large scale, e-commerce, tourism in that, commercial relations, as a result of the inability to fulfill their contractual obligations, which led jurists to rely on the theory of emergency conditions to explain the impossibility or difficulty of fulfilling the obligations of the contractors on the terms of contracts, and as a result of the occurrence of many contractual problems, the affect of a virus on the capacity of contractors to fulfill their obligations.

This article aims to analyze the impact of the spread of the virus on contractual obligations by relying on the force majeure theory, and the position of jurists on using this theory in explaining the impact of the spread of this epidemic on the ability of the contracting parties to fulfill their obligations.

The researcher has come out with a set of results, the most important of which is that the new Corona virus can be considered an obstacle or a force majeure, based on what was stated in the contents of the provisions of the relevant bodies, and this will have legal and economic implications for the contractual obligations of the various international commercial contracts.
\end{abstract}

Keywords: force majeure, Covid-19, contractual obligations, electronic commercial contracts

\section{Introduction}

The spread of the Corona virus led to a lot of losses for individuals and companies, which drew the attention of legal scholars, both at the international level and at the local level. On the grounds that the effects of the Corona virus extended to all economic, tourism and health fields, which is what I needed to put on the legal research table to learn how to deal with side effects from a legal point of view ${ }^{1}$.

Force majeure is a legal concept upon which the parties of a binding contract, legal obligation or procedure can base an exception to overrule the prevailing described terms. The COVID-19 pandemic brought new demanding situation to this matter, considering the long periods of lock-down which could alternate on a weekly basis and the corresponding adverse influences on change and commerce. This situation places the parties to the contract in an unsafe and uncertain position regarding the performance of their contractual obligations. Further one can question if the traditional legal mechanisms are sufficient and adequate to handle the upcoming paradigm where obligations are assumed or contracted by any relevant party within a pandemic scenario (which is no longer a novelty). Force majeure is a legal concept upon which the parties of a binding contract, legal obligation or procedure can base an exception to overrule the current defined terms. The COVID-19 pandemic delivered new challenges to this matter, considering the long periods of lock-down that can alternate on a weekly basis and the corresponding detrimental impacts on trade and commerce ${ }^{2}$.

\section{Force Majeure Theory}

\subsection{Definition of Force Majeure}

Force Majeure is in fact a threat to the sustainability of the implementation of work contracts because it does not

\footnotetext{
${ }^{1}$ chamiyassine, The legal effects of Corona virus - Covid 19 - on procedural deadlines in a civil lawsuit, Al-Ijtihad Journal for Legal Studies, Volume 9, Issue 4, Year 2020, p. 234.

${ }^{2}$ José Carlos Pinto Garcia Alves Cardoso, Force Majeure And Hardship Within The Context Of A Global Pandemic, European Approaches, Semi-Final C Eu And European Civil Procedure, Themis 2021, P2
} 
come from parties but rather from outside and is caused by natural disasters, and by applying the force majeure theory to the obligations of contractors, my understanding indicates the difficulty of completing the contract or the impossibility of implementing the contract, and jurists have released many terms on the application of force majeure On contracts such as excess match, superior force, impossibility to perform the contract, and foreign cause $^{3}$.

The creditor is entitled to damages in the event of unjustified or culpable nonperformance of the contract, as the case may be. A debtor invoking force majeure might also exempt from the contractual liability provided that the respective fortuitous event is in a distinctive causal link with the non-fulfillment of contract obligations ${ }^{4}$.

For an event to be considered as falling within the scope of (force majeure) it has to cumulatively meet some attributes imposed by the law such as: externality, unpredictability, and irresistibility ${ }^{5}$.

Force majeure is a form of the foreign cause that negates the causal relationship between the action of the official and the damage sustained by the plaintiff. For the application of force majeure, three conditions must be met:

The first condition: Unpredictability: the accident must be absolutely impossible to foresee so that it is impossible for the average person to foresee it. The expectation is at the time of the conclusion of the contract in contractual liability

The second condition: the impossibility of payment: the force majeure must be impossible to pay, and this impossibility must be absolute, as well as the force majeure that would make the implementation of the obligation impossible and not burdensome ${ }^{6}$.

The third condition: that the accident is beyond the person's control, it must stem from a factor external to the debtor, given that if it is attributed to him personally or due to his negligence, he will be responsible for its consequences, and he is also responsible for these consequences if they occur by the action of one of his subordinates or the objects or machines that under his hand or guarded ${ }^{7}$.

\subsection{The Effect of Force Majeure Theory on Electronic Commerce}

\subsubsection{Definition of E-commerce Contracts}

In general, electronic commerce can be described as commercial operations concluded through an electronic intermediary, which is a business, whether it is the sale or purchase of physical or other goods, or obtaining a service, or obtaining information, but all of this is done electronically. Where the seller, service producer or distributor presents his product and qualities, the contracting parties negotiate and issue the acceptance and offer necessary for concluding the contract, and they agree on the detailed terms for the implementation of the contract, by electronic means, whatever this means, although it is common nowadays to contract via the Internet, being A global spider network to access information everywhere at the lowest possible cost, while ensuring the largest possible amount of advertising for the product or service, and reaching the largest possible number of customers ${ }^{8}$.

Some jurisprudence defines an electronic contract as a contract that is concluded by electronic means wholly or partially, and the electronic means is any electrical, magnetic, optical, electromagnetic or any other similar means valid for exchanging information between the contracting parties. It was also known as an agreement in which the offer meets acceptance. Through an open international network for remote communication (the Internet) by an audio-visual means, and there are those who also know it as the meeting of acceptance and approval thanks to communication between the parties by an audio-visual means through an open international network for remote communication?.

The implementation of electronic commerce contracts differs from the implementation of traditional contracts,

\footnotetext{
${ }^{3}$ Nizam Zakka Arrizal, The Enforceability Force Majeure's Clause In Performance Of Business Contracts During Pandemic Covid-19 In Indonesia, 2nd International Conference on Law, Governance and Social Justice, ICOLGAS 2020, p410.

${ }^{4}$ viorelterzea, force majeure-a contract clause exempting parties from contractual liability, the international conference, europeanunion,s history, culture and citizenship, pitesti, 17-18 may 2019, p197

5 ibid, p194.

${ }^{6}$ some accounts, the value of online sales of tourism and travel services exceeds the value of even the categories of merchandise most commonly purchased online. See, for example, Kemp, S. (2019), Digital 2019: Global Digital Overview, Hootsuite and We Are Social, 31 January 2019, available at https://datareportal.com/reports/digital-2019-global-digital-ov

${ }^{7}$ Sherif Muhammad Ghanem, The Impact of Changing Circumstances on International Trade Contracts, United Arab Emirates, Al-Fajr International Press, 2010, p. 87

${ }^{8}$ Mobarka Hanan Karkouri, RedaHemisi, The mechanisms for the implementation of the electronic commerce (Comparative Study), Proceeding of Al Yamamah University Law Forum(YULAW2020), Riyadh, KSA, 1-2 March, 2020, p141.

${ }^{9}$ Ibid.
} 
because electronic commerce contracts raise some difficulties resulting from the privacy that characterizes these contracts, because they are done remotely using modern means of communication ${ }^{10}$.

Before the spread of a virus and after that, the issue of implementing electronic commerce contracts became one of the most important topics that the world is witnessing, especially with the expansion of the circle of contracts concluded through the Internet, to meet their needs that they were trying to obtain through traditional contracts.

\subsubsection{Effect of Covid-19 on Electronic Commerce}

the Corona virus effect on electronic commerce was positive, as it witnessed a remarkable recovery through the demand for electronic stores, in addition to holding remote meetings through video communication technology, with the decline in movement in traditional stores as a result of the spread of the Corona virus and in light of the current situation and the precautionary measures that it imposed Most of the world's countries to prevent this crisis, The demand for electronic stores has increased, as online shopping has become an important option for many, with the aim of obtaining their basic needs. Thus, websites specialized in buying and selling, as well as social networking sites, has become the destination of many citizens, especially after some of these sites launched a free delivery service to their homes. Without them having to go out, this is what made electronic commerce remarkably rebound under these exceptional circumstances ${ }^{11}$.

During the spread of the Corona pandemic, the demand for technology that allows for online meetings to be held increased, with the aim of maintaining the normal systems of business, so programs such as Zoom appeared that replaced actual meetings and gatherings with virtual meetings ${ }^{12}$.

The World Health Organization considered that the spread of the Corona pandemic is a global epidemic, and the precautionary measures and decisions taken by most countries to avoid the spread of the Corona virus were required by the current situation. Exhausting the debtor and this will undoubtedly raise a large number of cases of exemption from liability on the basis of force majeure before the courts.

\subsubsection{Legal Implications of Considering the Corona Pandemic as a Force Majeure}

When the conditions of the obstacle or force majeure that prevent the implementation of contractual obligations at the level of electronic commerce are available, this results in some legal effects in accordance with the United Nations Convention, where Article (79/5) summarized this effect as stipulated ("nothing in this article prevents anyone The two parties are not allowed to use any of their other rights other than the request for compensation in accordance with the provisions of this agreement"). But if the negotiation process fails, there is no way but to rescind the contract while retaining the aggrieved party's right to claim compensation. This was confirmed by several international agreements, including the Vienna Convention of 1980, where Article No. (81) stipulates that ("by rescinding the contract in the two parties becomes dissolved from the obligations imposed on them by the contract, without prejudice to any due exposure, and the termination does not affect any of the terms of the contract related to the settlement of disputes or any of its other provisions that regulate the rights and obligations of the parties resulting from the termination of the contract") $)^{13}$.

Article (79/1) of the United Nations Convention on International Contracts provides for similar protection provided by the provisions of force majeure, and it might also apply to international contracts unless the application of the agreement has been explicitly excluded before in the contract. The conditions of the Corona epidemic that prevent the implementation of the obligations of electronic commerce contracts are the two issues of exemption from compensation and the effect of the temporary impediment.

\subsection{Impact of Covid-19 on the Obligations of Contractors}

Law is the frame in every business activity; humanity can't be separated from business activities because human nature is an economic being as well as a social being, and almost all business activities or business sectors have been affected by the Covid-19 pandemic. Among them: transportation, hotels, tourism, malls, entertainment, restaurants, cafes, banking, and the impact on the above sectors is the decline in corporation profits due to lack of consumers ${ }^{14}$.

\footnotetext{
${ }^{10}$ issawysohila, Implementation of E-Commerce Contracts, Master Thesis, Abdel Rahman Mira University, Algeria, 2017, 2017., pp2-3

${ }^{11}$ RahmaBariq, Mohamed LakhdarDallaj, The impact of the corona pandemic on the implementation of contractual obligation and on electronic commerce, Journal of Law and Human Sciences, University of BadjiMokhtar, Algeria, year 2020, p74.

${ }^{12}$ ibid,p74

${ }^{13}$ Mohamed Karim Garouf, Limits of the impact of the emerging corona virus on contractual obligations to international trade contracts, Journal of Economic Integration, Volume 9, Issue 1, March 2021, pp 73-88

${ }^{14}$ Nizam Zakka Arrizal, op cit, p409
} 
The previous measures taken by countries under the current exceptional circumstances had a direct impact on the various economic, social and legal sectors, as some civil and commercial transactions were affected by these circumstances and it became difficult for the creditor to demand the debtor to implement his commitment in accordance with the mutual obligations agreed upon in the contract. Such circumstances of the Corona crisis, which did not exist at the time of contracting ${ }^{15}$.

There is no doubt that these obligations concluded between the contractors before the exceptional circumstances of the Corona crisis find it difficult in terms of their implementation in the future, especially after the end of the Corona crisis (Covid-19), and this is after the legal adaptation granted by the judge to this case (Corona crisis) in order to find solutions to it.

It should be noted that creating legal solutions with the aim of overcoming future disputes between contractors in light of the Corona crisis is the function of the law that aims to organize society, and that the idea of organization is undoubtedly heading towards the future, there is no doubt that the legal rules are based on the solutions that I devote to expectations, In the sense of looking at the considerations expected to occur at a later time.

There is no doubt that the idea of the contract is the law of the contracting parties based on three foundations, the first of which is legal based on the principle of the authority of the will, the second is moral, represented in respect for covenants, and the third is a social and economic character that is translated by the necessity of stable transactions.

Objectively, as emphasized by legal jurisprudence, they are a translation of the deep relations between law and economy on the one hand, and principles of morality on the other hand. What is described as irresponsible ${ }^{16}$.

It should be noted that epidemics impose themselves as a material fact that has negative effects on the obligations of the contractors and the fulfillment of contracts, and this is due to the suspension of many works and this leads to the interruption of the contractual association as a result of the stagnation that affected some investment sectors, which makes it not possible or at least hard to implement obligations or extend its implementation ${ }^{17}$.

Researcher sees that the contracting parties' failure to fulfill their contractual obligations does not mean that their contractual obligations are not completed after the expiry of the foreign cause that made it difficult or impossible to fulfill their obligations during the crisis period. And the judiciary in many cases where it was decided by the judiciary to restore the financial balance between the parties to the contract based on the force majeure theory.

Since the COVID-19 virus first appeared in December 2020, countries around the world have sought to impose travel bans, quarantining citizens and isolating those infected to stop the spread of the new virus. The spread of the virus continues to be massive worldwide, making it necessary to study the full impact of the epidemic and the ensuing emergency measures on international trade and the global economy, with many reporting major trade and operational disruptions, including layoffs, airport and port coverage, disruption of supply and distribution channels, and a lack of trained workers, and the weak regional and international demand.

Given the unusual nature of the emerging epidemic, attention in legal circles has focused on the possibility that parties to commercial contracts may invoke force majeure and other legal concepts in different legal systems in order to justify delays in the performance of their contractual obligations or to absolve them altogether.

Numerous force majeure claims involving a client or supplier in the global media, It seems likely that broader claims will follow, as the effects of the pandemic wave will spread around the world and any contract containing a specific force majeure clause may be the subject of a claim by the aggrieved party to these contracts ruled by the civil law framework for compensation or subsidies in the event that the epidemic is considered force majeure and whether the force majeure in this case was included in the contract or not, because the impact of the epidemic on the contracting parties is clear with emergency measures that affect goods, workers and logistics services, making them unable to fulfill their contractual obligations on time, which negatively affects local and global markets and causes disruptions ${ }^{18}$.

\footnotetext{
${ }^{15}$ Qajali Murad, Morabiten Sufian, The future of the implementation of contractual obligations in light of the exceptional circumstances of the Coronavirus (Covid-19), Algerian Journal of Legal and Political Sciences, Volume 58, Issue No. 2, Year 2021, pg.: 706-729.

${ }^{16}$ Galati Mansour, The Legal Effects of the Novel Coronavirus (Covid-19) on Contractual Obligations, Annals of the University of Algiers, Volume 34, Special Issue, Law and the Covid-19 Pandemic, pg.: 484-502.

17 ibid.

${ }^{18}$ Raja Hussain Al-Shteiwi, The Effects of the Coronavirus (Covid-19) on Contractual Obligations, Journal of Legal and Economic Studies, Volume 6, Summer 2020, p. 1.
} 


\section{Conclusion}

The aim of the research is to identify the legal effects of the spread of the Corona epidemic on electronic commerce, through the application of the force majeure theory, which sees the impossibility of the contracting parties to implement the terms of the contract or the difficulty of implementing the terms of the contract as a result of the occurrence of a foreign event or force majeure that prevents the contractors from completing the contract, which applies to me The Corona pandemic, which led to the disruption of many companies, and prevented individuals and organizations from completing their contracts as a result of closing borders between countries and the precautionary measures taken by many countries of the world to eliminate the Corona pandemic

It is clear from the opinions of legal scholars that there is a difference about the legal impact of the spread of the Corona virus on electronic commerce contracts.

Also It is clear from the opinions of legal scholars that when applying force majeure theory and analyzing the impact of the spread of the Corona virus and its effects on the obligations of contractors, especially in e-commerce contracts, it can be said that jurists and researchers find it difficult to develop a legal conception of the impact of this epidemic on e-commerce contracts, and this is mainly due to the speed of change in the spread of Disease, which leads to a change in the effects of the spread of the Corona virus on contracts in electronic commerce.

There are some jurists who see that the effects of the Corona virus are negative effects depending on the suspension of flights and the closure of borders, which leads to the difficulty or impossibility of companies and individuals fulfilling their contractual obligations even if the contracts were made electronically and remotely. For example, there are remote contracts that oblige the selling party to send his goods to the buyer, in this case, the seller's commitment to fulfill the provisions of the contract may be recorded or difficult due to the difficulty or impossibility of sending the goods to the buyer as a result of closing the borders and the precautionary measures taken by all countries of the world to eliminate the Corona epidemic.

The fulfillment of a contractual obligation should not create an excessive loss or sacrifice to the deprived party, which can occur if the parties were obliged to fulfill the agreement by all means without taking into consideration the principle of good faith, who imposes that the contract can't be fulfilled without taking into account the abnormal context of the global pandemic.

The exceptional nature of the Corona pandemic calls us to ask those in charge of judicial departments to apply the theory of force majeure and the theory of emergency conditions if necessary, because reality has proven that most creditors with rights, franchisees and those entitled to payments, installments and financial obligations arising from contracts refused requests to suspend or cancel financial dues, whether they were Due payments such as residential, commercial or professional rents or amounts due as a result of supplies of goods or services, and this is what prompted the governments of many countries to call for dialogue and negotiation and to establish the principle of understanding based on consensual between all partners, institutions, economic entities and contractual parties.

\section{References}

Chamiyassine. (2020). The legal effects of Corona virus - Covid 19 - on procedural deadlines in a civil lawsuit. Al-Ijtihad Journal for Legal Studies, 9(4).

Galati, M. (n.d.). The Legal Effects of the Novel Coronavirus (Covid-19) on Contractual Obligations. Annals of the University of Algiers, 34(Special Issue, Law and the Covid-19 Pandemic).

Issawy, S. (2017). Implementation of E-Commerce Contracts, Master Thesis, Abdel Rahman Mira University, Algeria.

José Carlos Pinto Garcia Alves Cardoso. (2021). Force Majeure and Hardship Within the Context of a Global Pandemic, European Approaches, Semi-Final C Eu and European Civil Procedure, Themis.

Mobarka, H. K., \& Reda, H. (2020). The mechanisms for the implementation of the electronic commerce (Comparative Study), Proceeding of Al Yamamah University Law Forum(YULAW2020), Riyadh, KSA, 1-2 March.

Mohamed, K. G. (2021). Limits of the impact of the emerging corona virus on contractual obligations to international trade contracts. Journal of Economic Integration, 9(1).

Nizam, Z. A. (2020). The Enforceability Force Majeure's Clause in Performance of Business Contracts During Pandemic Covid-19 In Indonesia, 2nd International Conference on Law, Governance and Social Justice, ICOLGAS.

Qajali, M., \& Morabiten, S. (2021). The future of the implementation of contractual obligations in light of the 
exceptional circumstances of the Coronavirus (Covid-19). Algerian Journal of Legal and Political Sciences, $58(2)$.

Rahma, B., \& Muhammad, L. D. (2020). The impact of the Corona pandemic on the Postal Union, electronic commerce. Journal of Law and Human Sciences, University of Badji Mokhtar, Algeria.

Raja, H. A.-S. (2020). The Effects of the Coronavirus (Covid-19) on Contractual Obligations. Journal of Legal and Economic Studies, 6.

Sherif, M. G. (2010). The Impact of Changing Circumstances on International Trade Contracts. United Arab Emirates, Al-Fajr International Press.

Some accounts, the value of online sales of tourism and travel services exceeds the value of even the categories of merchandise most commonly purchased online. See, for example, Kemp, S. (2019), Digital 2019: Global Digital Overview, Hootsuite and We Are Social, 31 January 2019. Retrieved from https://datareportal.com/reports/digital-2019-global-digital-ov

Viorelterzea. (2019). Force majeure-a contract clause exempting parties from contractual liability, the international conference, europeanunion,s history, culture and citizenship, pitesti, 17-18 may.

\section{Copyrights}

Copyright for this article is retained by the author(s), with first publication rights granted to the journal.

This is an open-access article distributed under the terms and conditions of the Creative Commons Attribution license (http://creativecommons.org/licenses/by/4.0/). 